九州大学学術情報リポジトリ

Kyushu University Institutional Repository

\title{
Early Development of Laboratory-reared Giant Croaker, Nibea japonica
}

Ide, Kentaro

Fishery Research Laboratory, Kyushu University

Yoshimatsu, Takao

Fishery Research Laboratory, Kyushu University

Hidaka, Hidemi

Fishery Research Laboratory, Kyushu University | Miyazaki Prefectural Sea-farming Association

Ishi, Tetsuro

Miyazaki Prefectural Sea-farming Association

https://doi.org/10.5109/24262

出版情報：九州大学大学院農学研究院紀要. 43 (1/2)，pp. 153-168，1998-11. Kyushu University バージョン：

権利関係 : 
J. Fac. Agr., Kyushu Univ., 43 (1·2), 153-168 (1998)

\title{
Early Development of Laboratory-reared Giant Croaker, Nibea japonica*
}

\author{
Kentaro Ide, Takao Yoshimatsu, Hidemi Hidaka** and Tetsuro Ishi***
}

Fishery Research Laboratory, Kyushu University, 'Tsuyazaki, Fukuoka 811-3304, Japan

(Received July 1, 1998 and accepted August 7, 1998)

\begin{abstract}
Fertilized eggs of giant croaker Nibea japonica were obtained from reared adult fish injected with gonadotrophic hormone. Larvae and juveniles were reared for 3 months on rotifers, Artemia nauplii, Tigriopus japonicus, fish eggs and larvae, and artificial feed. Early developmental stages in giant croaker are illustrated, with special reference to morphological transformations, fir development, squamation, and development of digestive tract.

The artificially fertilized cggs were $0.94 \pm 0.03 \mathrm{~mm}$ in mean diameter. Hatching occurred $2629 \mathrm{~h}$ after fertilization at water temperatures of $22.023 .5^{\circ} \mathrm{C}$. On the $3 \mathrm{~d}$ day after hatching, larvate compleled yolk absorption and started feeding at $3.09 \pm 0.08 \mathrm{~mm}$ in body length (BL). Notochord flexion started on the 11 th day at $4.88 \pm 0.21 \mathrm{~mm}$ BL. The morphological transition from the larval to the juverile stage occurred between $8.4 \mathrm{~mm}$ and $12.4 \mathrm{~mm} \mathrm{BL}$. Then all fin rays attained the adult complement. Squamation was completed at $8.4-12.9 \mathrm{~mm} \mathrm{BL}$, and rudimenfary pyloric cacca appeared when the larvae transformed into juveniles, at between $8.9 \mathrm{~mm}$ and $13.6 \mathrm{~mm}$ BI. Juveniles over $30 \mathrm{~mm}$ BL, completed the formation of adult-like digestive system. Three marked chlanges appeared in the relative growths at approximately 4-5 $\mathrm{mm}, 8-11 \mathrm{~mm}$ and $30-35 \mathrm{~mm} \mathrm{Bl}$. These morphological changes corresponded to the notochord flexion, the transformations from larva to juvenile and from juvenile to young, respectivcly.
\end{abstract}

\section{INTRODUCTION}

Many of sciaenid fishes are commercially important especially as material for surimi-based products in Japan. In Korea, a dried sciaenid Larimichthys polyactis is known to be indispensable as material for special events and has very high commercial value. Recently natural stocks of sciaenids have been decreasing mainly due to over fishing (Ochiai and Tanaka, 1986). Therefore, there is a need for the rapid establishment of culture technology for sciaenids.

Giant croaker Nibea japonica is one of the largest sciaenids reaching about $1.2 \mathrm{~m}$ in body length (BL), and is distributed along the southern coasts of Japan and the East China Sea (Masuda et al., 1984). In Japan, the culture of this species started in the 1960 s using field collected natural fry at Miyazaki prefecture, Kyushu island, and later artificially produced fry took the place of natural fry (Tabaru et al., 1988). However little is known about seedling fry production and mariculture (Takeda et al., 1994; Han et al., 1994; El-Zibdeh et al, 1995a, b, c) in spite of their obvious importance to fish culture.

In this report, the ontogeny and the morphological characteristics with special reference to fin development, squamation and the development of digestive systems are described in detail from a series of reared specimens to provide more information on the

\footnotetext{
* Contribution from Fishery Research Laboratory, Kyushu University, No. 224.

** Miyazaki Prefectural Sea-farming Association, Nobeoka, Miyazaki 889-0322, Japan
} 
early life history of giant croaker and to get basic knowledge for the establishment of the fry production technology of sciaenids.

\section{MATERIALS AND METHODS}

\section{Artificial fertilization of eggs}

Fertilized eggs were obtained by natural spawning in a broodstock tank with 16 mature fish (male:fernale $=6: 10 ; 96.9-139.6 \mathrm{~cm}$ in total length, $9.3-11.3 \mathrm{~kg}$ in body weight) on May 24, 1996, at Miyazaki Prefectural Sea-Farming Center. Maturation was induced by a single intramuscular injection of gonadtrophic hormone, "Gonatropin" (1500 IU/individual) before the onset of spawning. The floating, fertilized eggs were collected and transported to the Fishery Research Laboratory of Kyushu University. Eggs were incubated in $500 l$ polycarbonate tanks held in a water bath warmed by a titanium heater at an initial density of $10,000-20,000 \mathrm{eggs} / \mathrm{kl}$.

\section{Larval and juvenile rearing}

The newly hatched larvae were reared in still sand-filtered seawater (salinity: 30-33 ppt) for the first 2 days, thereafter a flow-through system was employed. Larvae were fed with S-type marine rotifer Brachionus rotundiformis enriched with n-3 HUFA until the 19 th day after hatching. From 16th to 26th day after hatching they were fed HUFA-cnriched Artemia nauplii, from 16th to 25th day after hatching they were fed cultivated copepods Tigriopus japonicus, and from 20 th to 28 th day after hatching they are fed live eggs and larvae of black sea bream Acanthopagrus schlegeli. Subsequently they were fed a commercial artificial feed for marine fish (Mercian Co., Ltd. Japan). Deposits were siphoned from the tank bottom every morning. The water temperature during the experimental period ranged from $21.81029 .4^{\circ} \mathrm{C}$.

\section{Observations and measurements}

After being anesthetized with a small amount of MS-222 (3-Aminobenzoic acid ethyl ester), morphological observations and measurements of body length were made on 20-30 live specimens sampled every day until 27 days after hatching, and thereafter at, intervals of several days. After preservation in $5-10 \%$ neutralized formalin solution, the fish were measured for body length (BL), total length (TL), head length (HL), body depth at the portion of pectoral fin (BD), upper jaw length (UJL), eye diameter (ED), pre-anal length (PAL), the distance between ventral fin and anus (DVA), and pre-dorsal fin length (PDL). Body weight was measured by weighing 20 preserved individuals together (duplicate, < ca. $7 \mathrm{~mm} \mathrm{TL}$ ) or individually (>ca. $7 \mathrm{~mm}$ TL), after carefully removing body surface water with filter paper. Preserved specimens were also used for examining fin development and squamation, and the development of the digestive tract. For fin development and squamation specimens were stained with Alizarin Red-S.

\section{RESULTS AND DISCUSSION}

\section{Embryonic development}

The eggs were transparent, non-adhesive, pelagic, and circular in shape, measuring 
Table 1. Embryonic development of Nibea japonica

\begin{tabular}{|c|c|c|c|}
\hline Time (hr:min) & WT $\left({ }^{\circ} \mathrm{C}\right)$ & Figure (Fig.1) & Descriptions \\
\hline $0: 00$ & 22.0 & A & Fertilized egg \\
\hline $1: 30$ & 22.4 & $\mathrm{~B}$ & 8 cells \\
\hline 3:00 & 22.7 & $\mathrm{C}$ & Monila \\
\hline $4: 30$ & 22.7 & $\mathrm{D}$ & Gastrula \\
\hline $9: 00$ & 23.1 & & Blastoderm $2 / 3$ of yolk-sac \\
\hline $11: 00$ & 22.9 & $\mathrm{E}$ & $\begin{array}{l}\text { Blastoderm } 3 / 4 \text { of yolk-sac, formation of } \\
\text { embryonal body, blastopore nearly closed }\end{array}$ \\
\hline $12: 30$ & 22.9 & $\mathrm{~F}$ & $\begin{array}{l}\text { Formation of eye vesicles, Kupffer's vesicles } \\
\text { and } 10 \text { somites, melanophores appearing on } \\
\text { dorsal part of embryo and oil globule, } \\
\text { xanthophores appearing on almost whole } \\
\text { part of embryo and lower part of oil globule }\end{array}$ \\
\hline $21: 30$ & 23.5 & $\mathrm{G}$ & $\begin{array}{l}\text { Embryonal body } 3 / 4 \text { of yolk-sac, } 20 \text { somites, } \\
\text { disappearance of Kupffer's vesicles, } \\
\text { formation of auditory vesicles and eye lenses }\end{array}$ \\
\hline $24: 00$ & 23.5 & & $\begin{array}{l}\text { Heart pulsation began } \\
\text { Embryo wriggled occasionally }\end{array}$ \\
\hline $26: 30$ & 23.5 & & Free larva, hatching began \\
\hline $29: 00$ & 23.5 & & Hatching completed \\
\hline
\end{tabular}

$942.3 \pm 28.9 \mu \mathrm{m}(\mathrm{n}=100$, mean $\pm \mathrm{SD})$ in diameter with a single oil globule $(284.1 \pm 31.3 \mu \mathrm{m}$ in diameter). The perivitelline space was narrow. The embryonic development is summarized and shown in Table 1 and Fig. 1, respectively. Most of the eggs hatched within $26-29 \mathrm{~h}$ incubation at $22.0-23.5^{\circ} \mathrm{C}$.

\section{General morphology and behavior of larvae and juveniles}

The change in mean body length over the first 97 rearing days is shown in Fig. 2. The body length of newly hatched larvae (Fig. $3 \mathrm{~A}$ ) was $1.87 \pm 0.09 \mathrm{~mm}$. The anus was situated slightly posterior to the middle of the body. The total number of somites was generally 27 $(8+19$; pre-anal + post-anal). The oil globule was situated posterior to the yolk-sac. Melanophores were present on the top of the head, the edge of the eye, the snout-tip, the trunk and caudal regions, and the dorsal side of the oil globule. Xanthophores were present on the edge of the eye, trunk, and caudal regions, and the ventral side of the oil globule. They had unpigmented eyes, no fins, and the mouth had not yet formed. They floated motionlessly, below the water surface with the ventral side up.

The 1-day yolk-sac larvae (Fig. 3B) were $2.89 \pm 0.15 \mathrm{~mm}$ BL. The number of somites was $6+19=25$. They had pigmented eyes and a marked batch of melanophores and xanthophores extending radially into the dorsal fin-hold above the fan-shaped pectoral fins. The 3-day yolk-sac larvae (Fig. 3C) were $3.09 \pm 0.08 \mathrm{~mm}$ BL. The mouth was open, but not yet functioning. The first inflation of the gas bladder was observed in almost all individuals. As the larvae completed yolk absorption, they started feeding on rotifers.

The 5-day pre-flexion larvae (Fig. 3D) were $3.36 \pm 0.13 \mathrm{~mm}$ BL. Melanophores were present on the shoulder, the top of gas bladder and digestive.tract, the ventral side of 


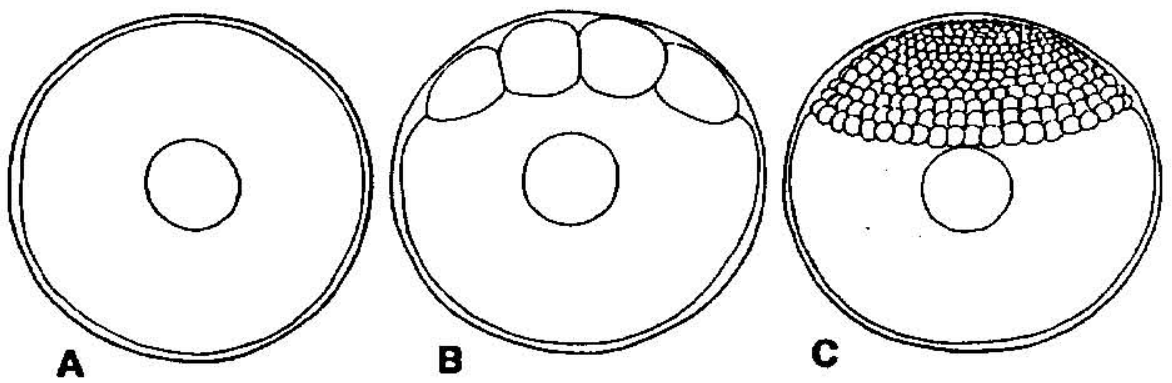

A

$\mathbf{B}$
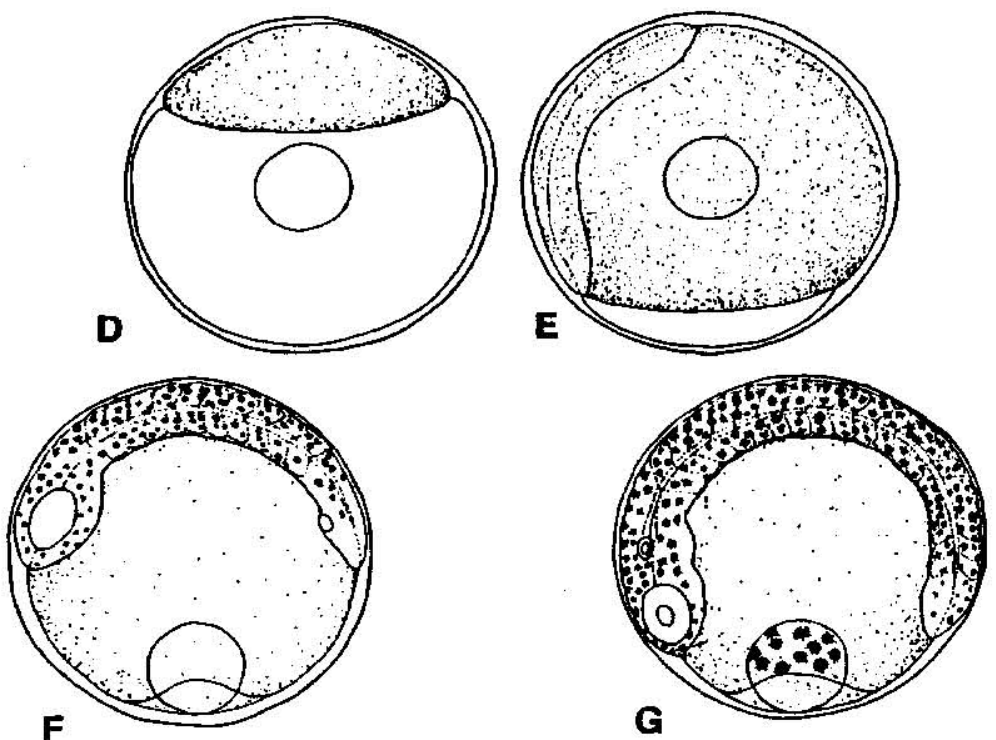

Fig. 1. Embryonic development of Nibea japonica at $22.0-23.5^{\circ} \mathrm{C}$

A, immediately after fertilization; B, 1 h30 min; C, 3 h; D, 4 h30 min; F, 11 h; F, 12 h30 min; G, $21 \mathrm{~h} 30 \mathrm{~min}$.

caudal region, and hindgut. The 9-day pre-flexion larvae (Fig. 3E) were $4.33 \pm 0.16 \mathrm{~mm}$ BL. A rudimentary caudal fin appeared. Melanophores were conspicuous around the rudimentary caudal fin.

The 11-day flexion larvae (Fig. $3 F$ ) were $4.88 \pm 0.21 \mathrm{~mm} \mathrm{BL}$. The notochord had started to flex upwards. The anlagen of dorsal and anal fin rays appeared. Tiny jaw tecth appeared. The 13-day flexion larvae (Fig. 3G) were 5.44 $\pm 0.40 \mathrm{~mm}$ BL. Melanophores on the dorsal surface of visceral cavity became heavy.

The 16-day post-flexion larvae (Fig. 3H) were $5.69 \pm 0.31 \mathrm{~mm}$ BL. Rudimentary ventral fins appeared. The 20-day post-flexion larvae (Fig. 3I) were $7.16 \pm 0.95 \mathrm{~mm}$ BL. Segmentation of the caudal fin ray was initiated. The nostril became comma-shaped.

The 23-day transformation larvae (Fig. 3J) were $8.11 \pm 1.09 \mathrm{~mm} \mathrm{BL.} \mathrm{Most} \mathrm{individuals}$ had fully developed fin rays and all the fin ray counts completed. The tail became almost 

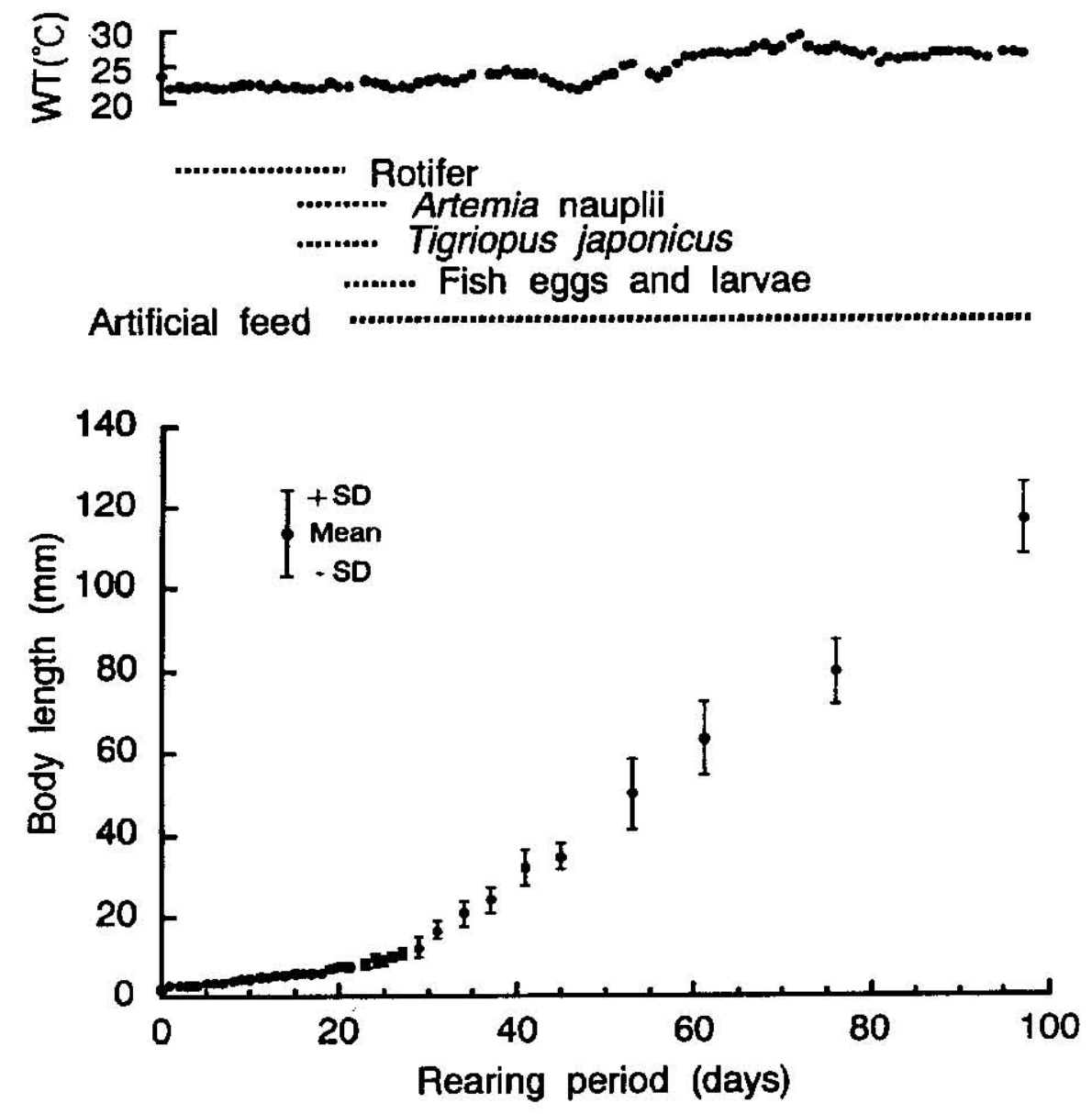

Fig. 2. Mean growth of Nibea japonica in body length, feeding schedule, and water temperature (W. T.) during the first 97 days of the rearing experiment.

symmetry in shape. Scales appeared along the anterior portion of the tail at an approximate size of $8.4 \mathrm{~mm}$ BL.

The 26-day juveniles (Fig. $3 \mathrm{~K}$ ) were $10.1 \pm 1.3 \mathrm{~mm}$ BL. The nostril separated into two pairs. Melanophores on the body surface became most remarkable that made a strong impression on the fish in this stage. Fish began to change their swimming stratum from the surface to a more benthic portion in the rearing tank. The 34-day juveniles (Fig. $3 \mathrm{~L}$ ) were $20.8 \pm 3.3 \mathrm{~mm}$ BL. The anus sifted to backward. The characteristic longitudinal melanophore bands appeared on the body surface.

The 53-day young (Fig. $3 \mathrm{M}$ ) were $49.9 \pm 8.6 \mathrm{~mm}$ BL. The snout became overhanging beyond the mouth. Melanophores on the body surface were not distinct any more, 

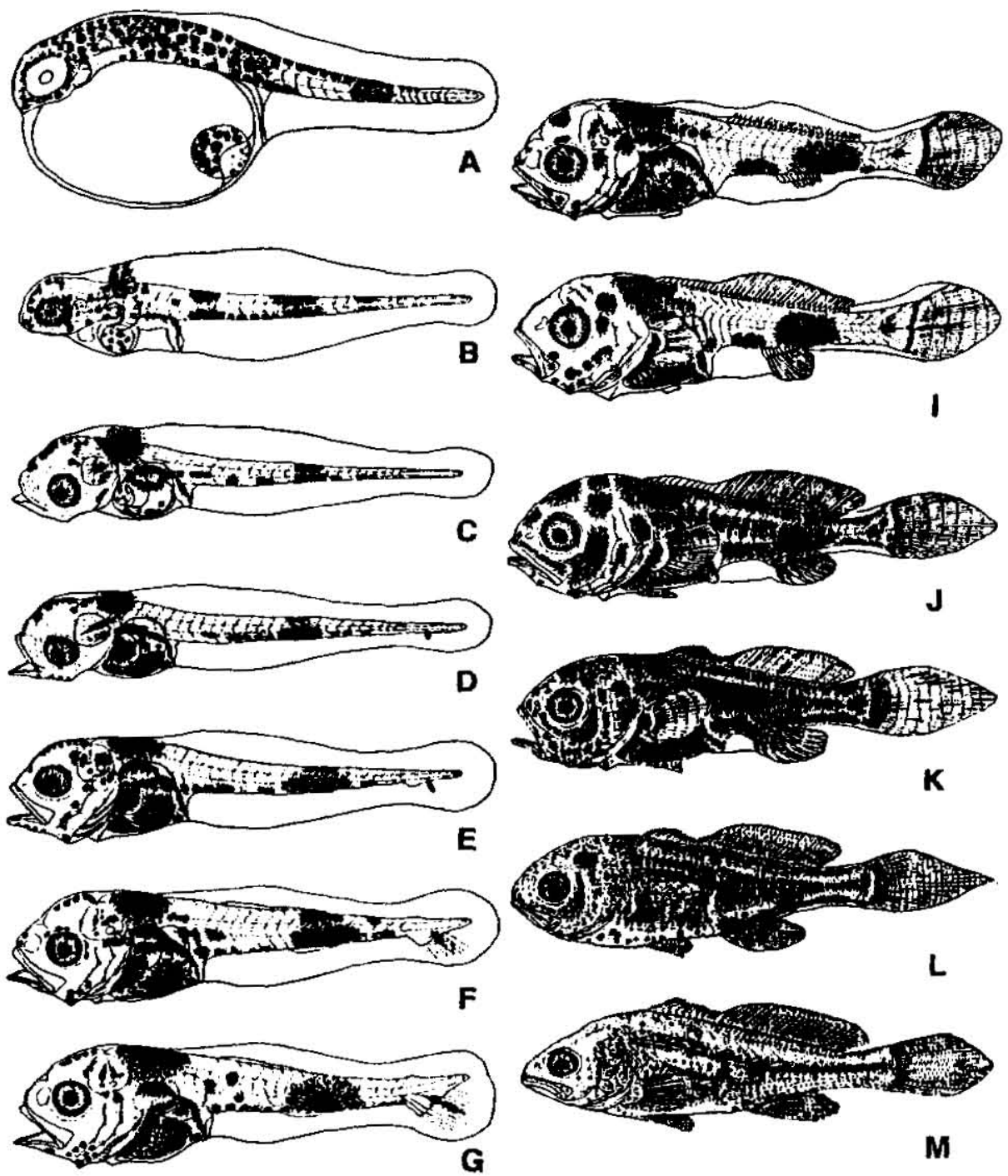

Fig. 3. Nibea japonica reared in the laboratory.

A, $1.87 \mathrm{~mm} \mathrm{BL} ; B, 2.89 \mathrm{~mm} \mathrm{BL} ;$ C, $3.09 \mathrm{~mm} \mathrm{BL} ;$ I), $3.36 \mathrm{~mm} \mathrm{BL} ; \mathrm{E}, 4.33 \mathrm{~mm} \mathrm{BL} ; \mathrm{F}, 4.88 \mathrm{~mm}$ BL; G, $5.44 \mathrm{~mm} \mathrm{BL;} \mathrm{H,} 5.69 \mathrm{~mm} \mathrm{BL;} \mathrm{I,} 7.16 \mathrm{~mm} \mathrm{BL} ; \quad J, 8.11 \mathrm{~mm} \mathrm{BL;} \mathrm{K,} 10.1 \mathrm{~mm} \mathrm{BL;} \mathrm{L}$, $20.8 \mathrm{~mm}$ BL; M, $49.9 \mathrm{~mm}$ BI. 


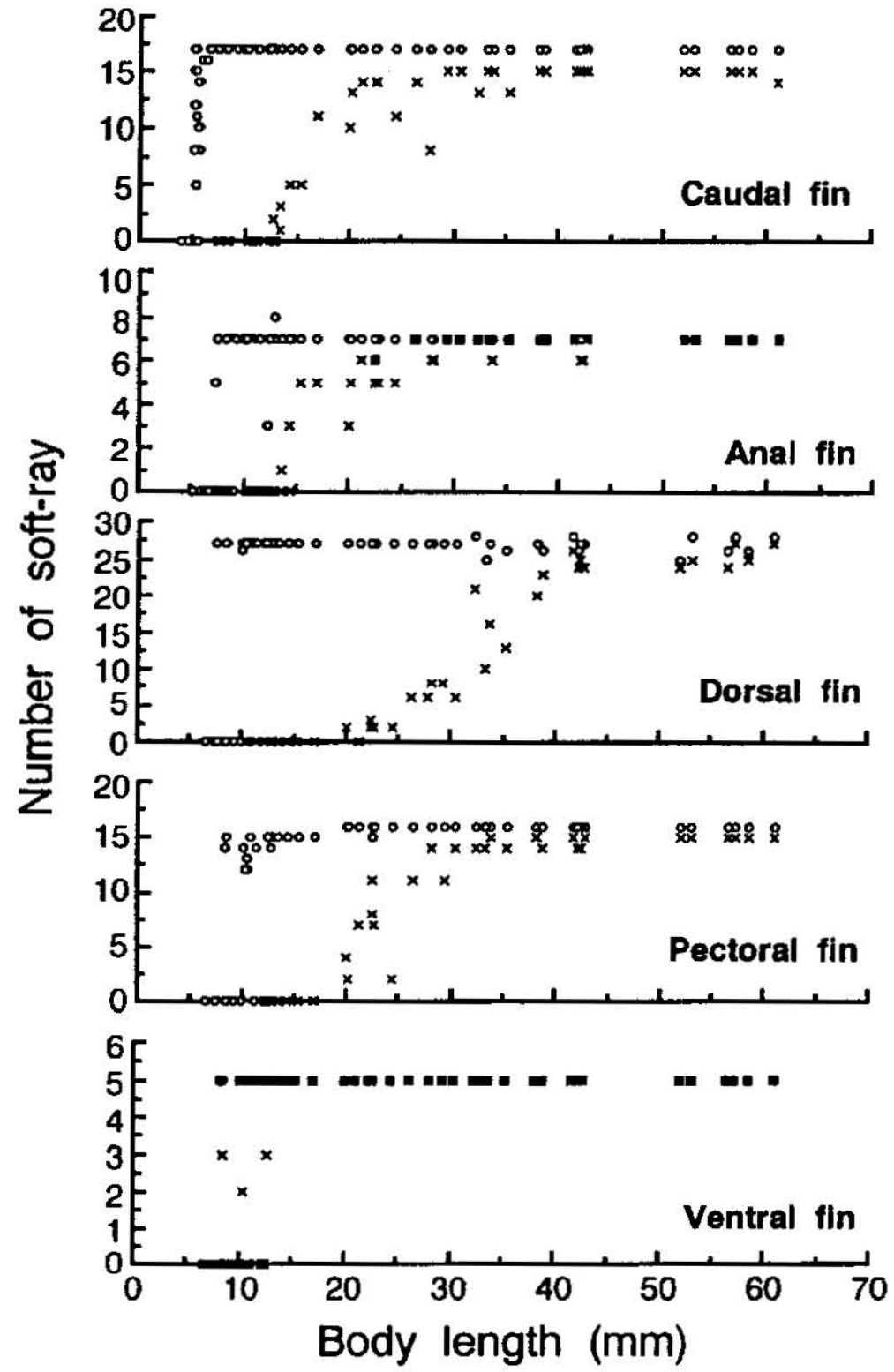

Fig. 4. Segmentation (open circles) and branching (cross) of soft ray on the unpaired and paired fins in Nibea japonica. 
compared with those of the fish in the previous stages. Their body were covered with guanine and appeared silver. The shape of the caudal fin resembled that of on adults.

\section{Fin development}

A full complement of fin rays occurred at $8.4 \mathrm{~mm}$ BL in the smallest specimen, and at $12.4 \mathrm{~mm} \mathrm{BL}$ in the largest one, thus the transformation from the larvae to juvenile stage occurred at $8.4 \mathrm{~mm}$ to $12.4 \mathrm{~mm}$ BL (Fig. $3 \mathrm{~J}, \mathrm{~K}$ ) at $21.8-29.4^{\circ} \mathrm{C}$. After a full complement of soft rays in each fin was completed, segmentation of rays began, occurring earlier in unpaired fins than in paired fins (Fig. 4). This fin developmental pattern well agreed and was similar to those of other many teleosts, such as Japanese anchovy Engraulis
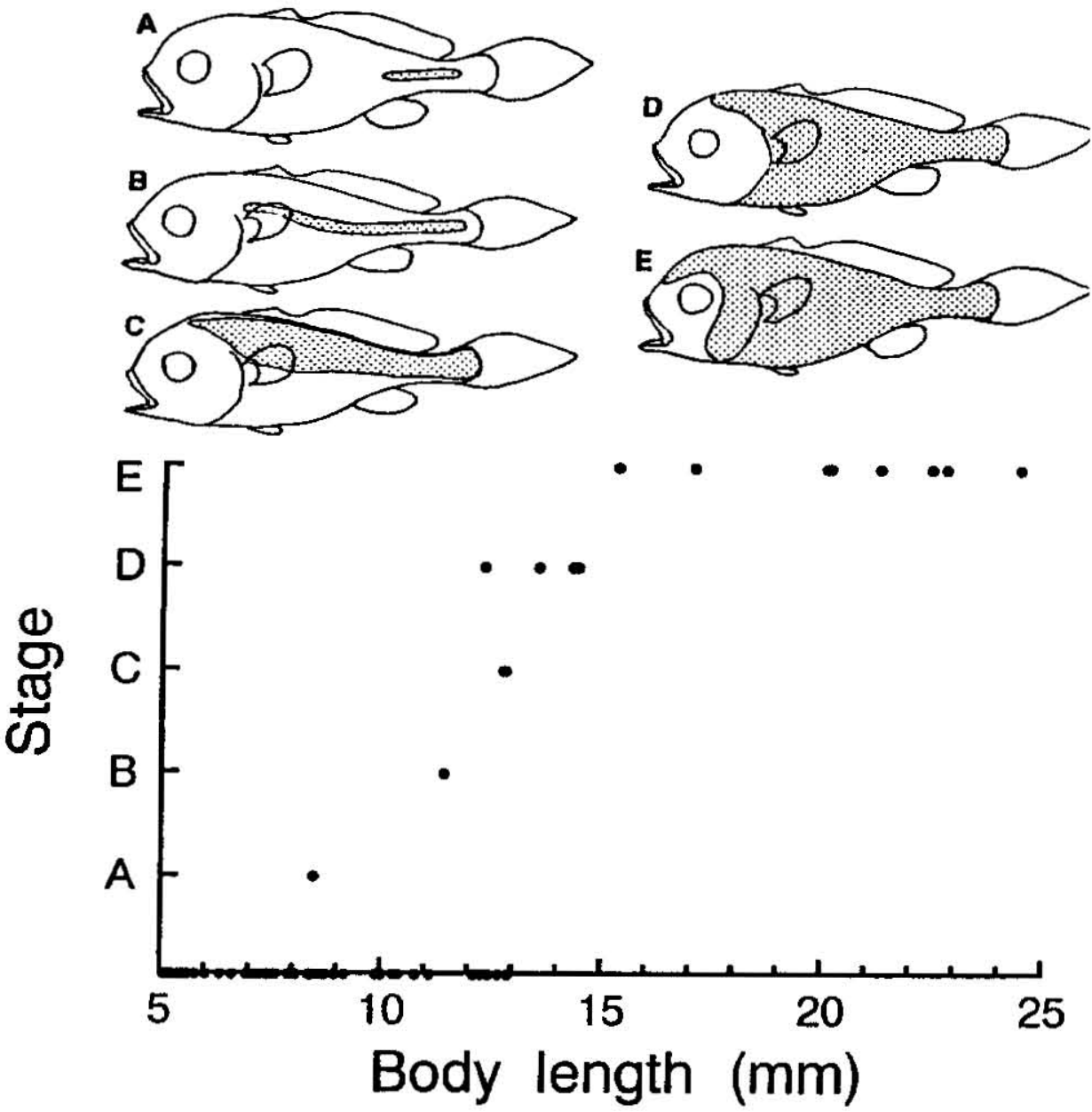

Fig. 5. Schematic illustrations showing developmental stages of squamation (upper), and plots of the stages against body length (lower) in Nibea japonica. 
japonica, ayu Plecoglossus altizelis, red sea bream Pagrus major, black sea bream (Fukuhara, 1992), and mullets Liza haematocheila and L. affinis (Yoshimatsu, 1996). Caudal fin rays began to segment at about $5.1 \mathrm{~mm}$ BL, anal fin at $7.2 \mathrm{~mm}$ BL, dorsal fin at $7.4 \mathrm{~mm}$ BL, ventral and pectoral fins at $8.3 \mathrm{~mm}$ BL. The completion of segmentation in the fin was achieved at $12.1 \mathrm{~mm}$ BL in the anal, $12.4 \mathrm{~mm}$ BL in the ventral, $22.7 \mathrm{~mm}$ BL in the pectoral, $6.4 \mathrm{~mm} \mathrm{BL}$ in the caudal and $10.0 \mathrm{~mm}$ BL in the dorsal fin, respectively.

Branching of soft-rays began after the segmentation was completed, except for the ventral fins. Soft-ray branching was observed at approximately $8.4 \mathrm{~mm}$ BL in the ventral, $12.8 \mathrm{~mm}$ BL in the caudal, $13.5 \mathrm{~mm}$ BL in the dorsal, $13.5 \mathrm{~mm}$ BL in the anal and $20.0 \mathrm{~mm}$ $\mathrm{BL}$ in the pectoral. Branching was completed at $32.3 \mathrm{~mm}$ BL in the caudal, $42.4 \mathrm{~mm} \mathrm{BL}$ in the anal, $41.7 \mathrm{~mm} \mathrm{BL}$ in the dorsal, $12.7 \mathrm{~mm} \mathrm{BL}$ in the ventral and $42.4 \mathrm{~mm} \mathrm{BL}$ in the pectoral fin. Consequently all fins were completely segmented by $22.7 \mathrm{~mm} \mathrm{BL}$, and were branched when fish reached $42.4 \mathrm{~mm}$ BL.

\section{Squamation}

Squamation proceeded with larval growth. The largest individual without scales was $12.9 \mathrm{~mm} \mathrm{BL}$, while the smallest with scales was $8.4 \mathrm{~mm} \mathrm{BL}$. Squamation started along the mid-lateral part of the body (Fig. 5A) and expanded rapidly, having clearly covered the entire body including the operculum region in the juveniles of about $15 \mathrm{~mm} \mathrm{BL}$ (Fig. 5B-E).

\section{Development of digestive tract}

The digestive system of a reared adult ( $23.4 \mathrm{~cm} \mathrm{BL}, 142 \mathrm{~g} \mathrm{BW}$ ) is shown in Fig. 6 . The stomach was elongated $\mathrm{Y}$-shape with eight pyloric caeca. The intestine was coiled simply in the visceral cavity, and its convolution type was similar to those of red sea bream, black

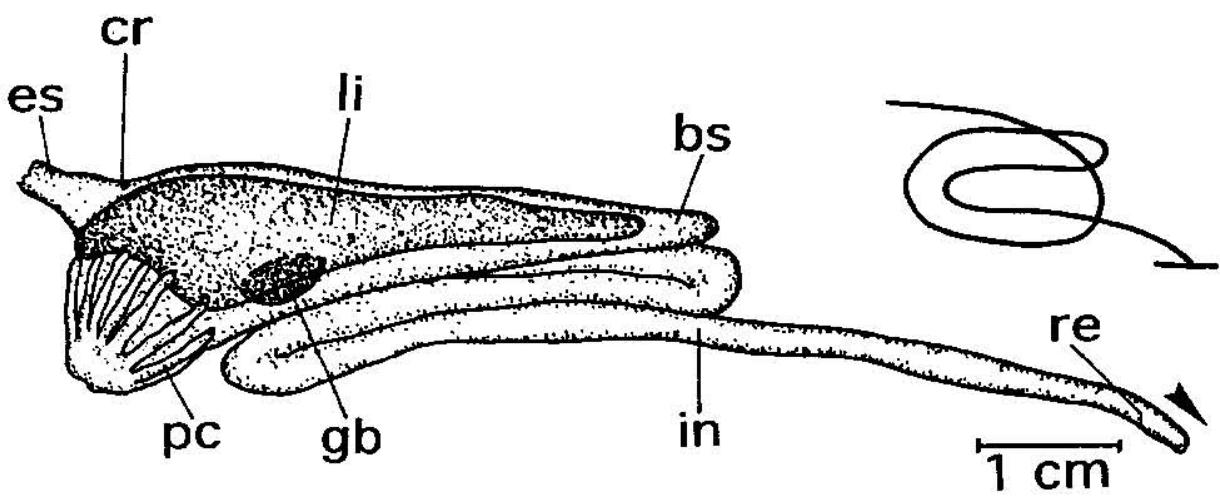

Fig. 6. Digestive system and schematic illustration of the convolution of intestine in adult Nibea japonica (lateral view from left side). es, esophagus; $c r$, cardiac region; bs, blind sac; li, liver; in, intestine; re, rectum; gb, gall bladder; pc, pyloric caeca; Arrow indicates the direction to the anus. 


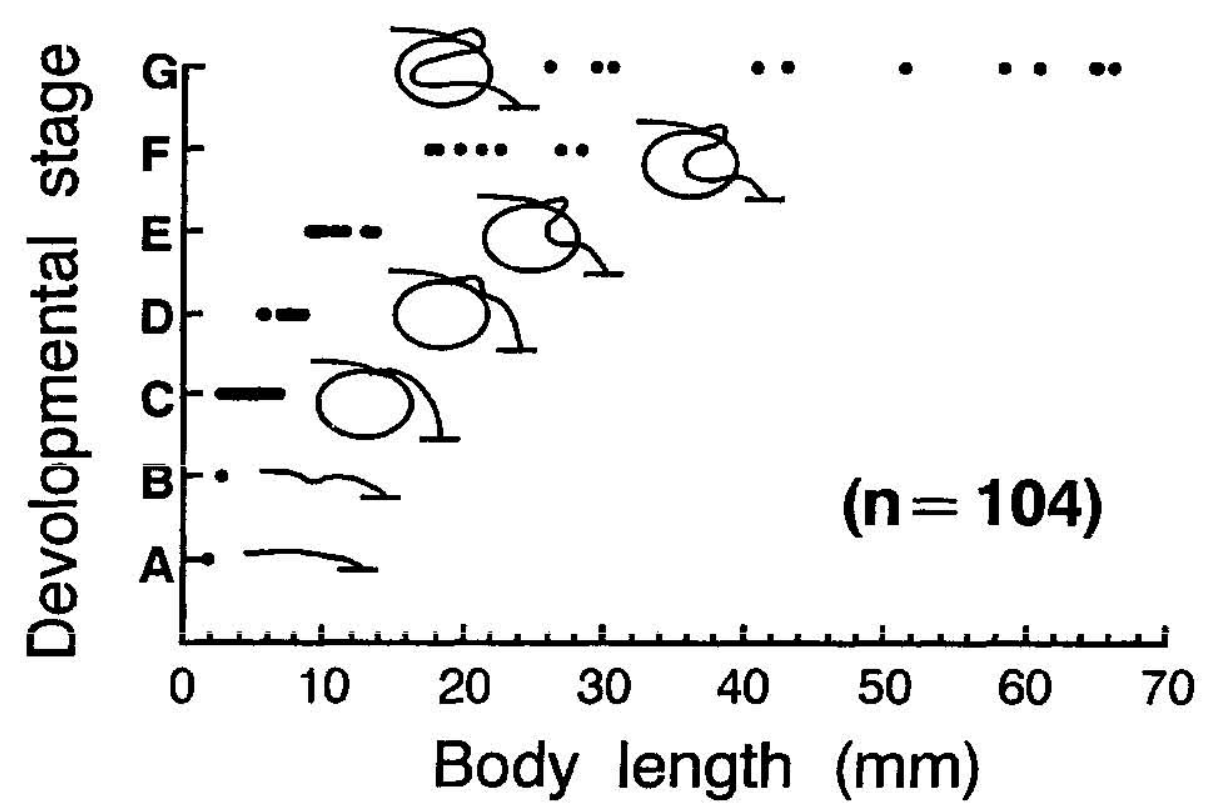

Fig. 7. Developmental stages of digestive tract plotted against body length in Nibea japonic:a $(\mathrm{n}=104)$.

sea bream (Fukuhara, 1992) and silver sea bream Sparus sarba (Tsukashima and Kitajima, 1982). The development of the digestive system during the early developmental stages and its relationship to body length are shown in Fig. 7. The digestive tract of newly hatched larvae was unlooped (Fig. 7A). The coiled digestive tract was formed when larvae attained more than $2.7 \mathrm{~mm}$ BL (Fig. 7C). The stomach was formed, and posterior portion of the digestive tract was curved slightly (Fig. 7D) when larvae reached the size of $5.6 \mathrm{~mm}$ to $8.5 \mathrm{~mm} \mathrm{BL}$. The pyloric caeca appeared (Fig. 7E), corresponding to the transformation from the larval to juvenile stages. The specimens over $17.5 \mathrm{~mm}$ BL had well-devcloped pyloric caeca (Fig. 7F). According to the progress in early development, pyloric caeca elongated and the shape of digestive tract of the specimens over $30 \mathrm{~mm}$ BL became deeply rounded and curved quite similar to that of an adult (Fig. 7E).

\section{Relative growth}

The body length (BL, mm)-body weight (BW, mg) relation is shown in Fig. 8. Allometric equations of the relationships are shown below. Inflexions generally corresponding to the period of the notochord-flexion and the two endings of larval and juvenile stages appeared at $4.18 \mathrm{~mm}, 8.92 \mathrm{~mm}$ and $34.2 \mathrm{~mm}$ BL, respectively.

$$
\begin{aligned}
& \mathrm{BW}=1.091 \times 10^{-2} \mathrm{BL}^{2445}(\mathrm{r}=0.963) 2.98 \mathrm{~mm}<\mathrm{BL}<4.18 \mathrm{~mm} \\
& B W=5.475 \times 10^{-4} \mathrm{BL}^{+.635}(\mathrm{r}=0.971) 4.18 \mathrm{~mm}<\mathrm{BL}<8.92 \mathrm{~mm} \\
& \mathrm{BW}=1.329 \times 10^{-2} \mathrm{BL}^{3.1 .88}(\mathrm{r}=0.973) 8.92 \mathrm{~mm}<\mathrm{BL}<22.6 \mathrm{~mm}
\end{aligned}
$$




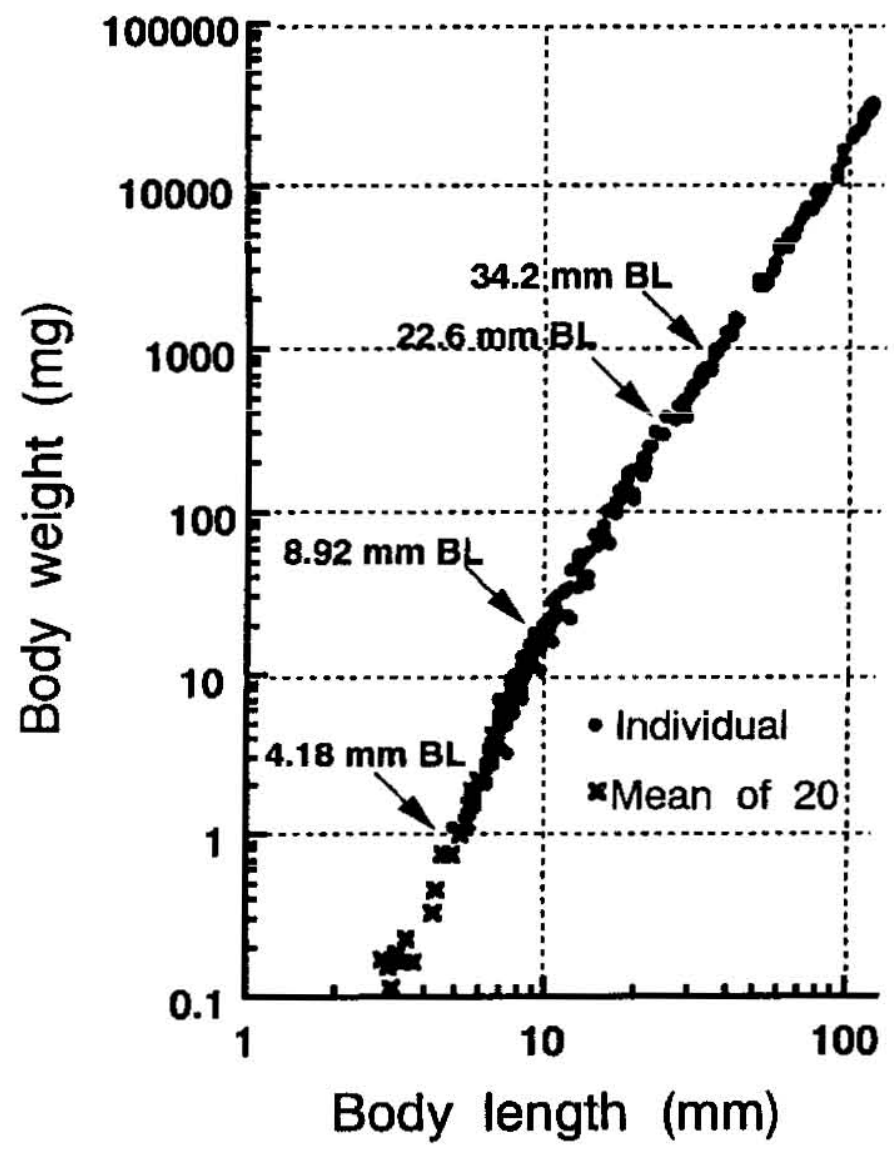

Fig. 8. Body length (BL, mum)-body weight (BW, mg) relationship of Nibea japonica. Arrows show growth inflexions.

$\mathrm{BW}=9.774 \times 10^{-2} \mathrm{BL}^{2598}(\mathrm{r}=0.988) 22.6 \mathrm{~mm}<\mathrm{BL}<34.2 \mathrm{~mm}$

$\mathrm{BW}=2.510 \times 10^{-2} \mathrm{BL}^{2.923}(\mathrm{r}=0.997) 34.2 \mathrm{~mm}<\mathrm{BL}<121.0 \mathrm{~mm}$

Proportional changes of various parts of the body against body length are shown in Fig. 9, and the equations for each relative growth are listed below.
$\mathrm{TL}=1.012 \mathrm{BL}^{1.043}$ $(\mathrm{r}=0.992) 1.54 \mathrm{~mm}<\mathrm{BL}<4.26 \mathrm{~mm}$
$\mathrm{TL}=7.592 \times 10^{-1} \mathrm{BL}^{\mathrm{t:242}} \quad(\mathrm{r}=0.994) 4.26 \mathrm{~mm}<\mathrm{BL}<10.7 \mathrm{~mm}$
$\mathrm{TL}=1.600 \mathrm{BL}^{\mathrm{n} .927} \quad(\mathrm{r}=0.997) 10.7 \mathrm{~mm}<\mathrm{BL}<29.7 \mathrm{~mm}$
$\mathrm{TL}=1.374 \mathrm{BL}^{\mathrm{v.972}} \quad(\mathrm{r}=0.996) 29.7 \mathrm{~mm}<\mathrm{BL}<124.4 \mathrm{~mm}$

$\mathrm{HL}=1.194 \times 10^{-1} \mathrm{BL}^{1.1 .19} \quad(\mathrm{r}=0.975) 2.64 \mathrm{~mm}<\mathrm{BL}<5.32 \mathrm{~mm}$ 


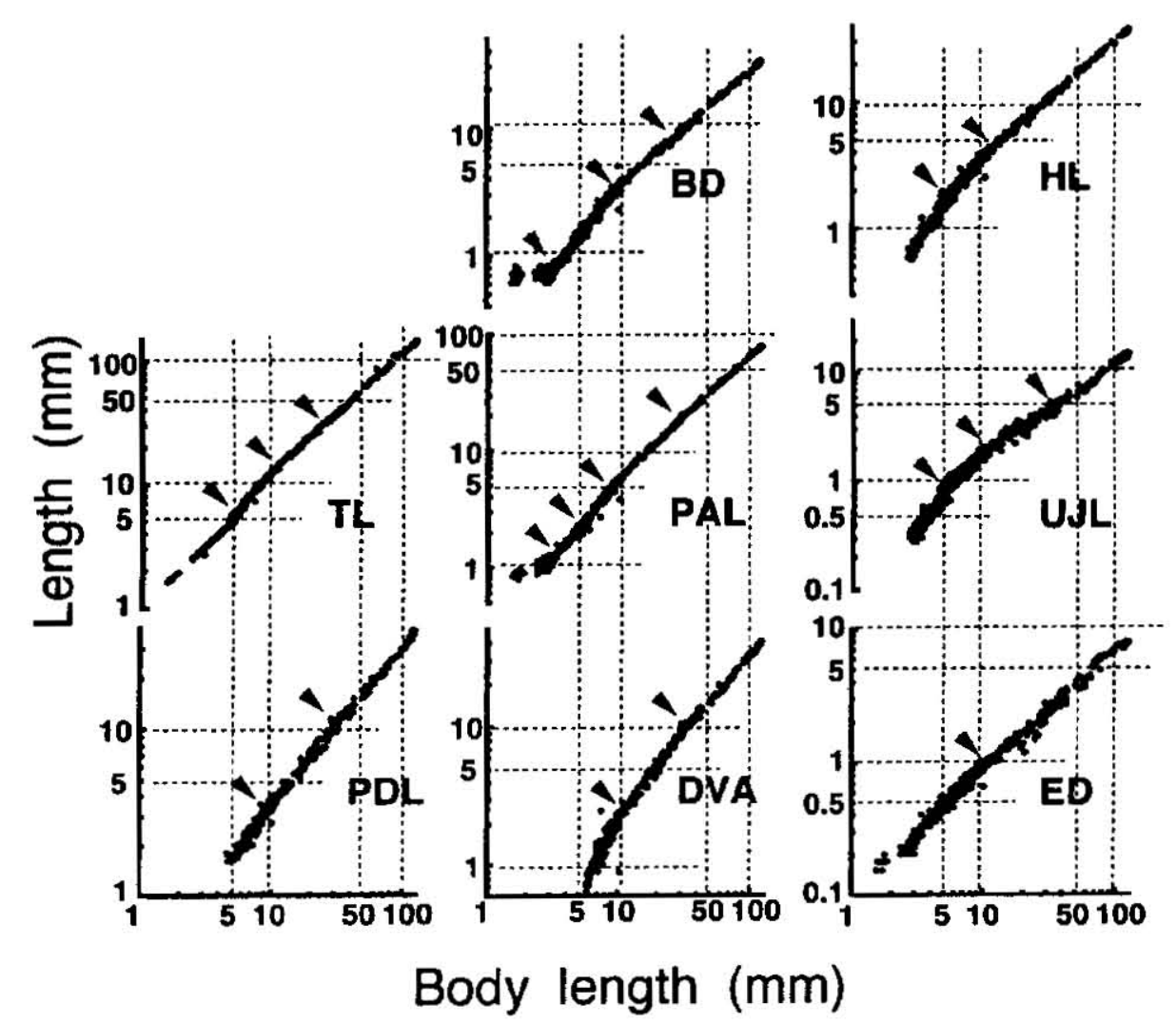

Fig. 9. Relative growth of total length (TL), body depth at the portion of pectoral fin (BD), upper jaw length (UJIL), eye diameter (EI)), pre-anal length (PAL), The distance belween ventral fin and anus (DVA), and pre-dorsal fin length (PDL) against body length (BL) of Nibea japonica $(\mathrm{n}=603)$. Arrows show growth inflexions.

$$
\begin{array}{ll}
\mathrm{HL}=2.419 \times 10^{1} \mathrm{BL}^{1.147} & (\mathrm{r}=0.965) 5.32 \mathrm{~mm}<\mathrm{BL}<10.8 \mathrm{~mm} \\
\mathrm{HL}=4.820 \times 10^{-1} \mathrm{BL}^{1.1 .223} & (\mathrm{r}=0.990) 10.8 \mathrm{~mm}<\mathrm{BL}<124.4 \mathrm{~mm} \\
& \\
\mathrm{BD}=1.033 \mathrm{BL}^{2.455} & (\mathrm{r}=0.954) 1.54 \mathrm{~mm}<\mathrm{BL}<2.75 \mathrm{~mm} \\
\left.\mathrm{BD}=1.794 \times 10^{-1} \mathrm{BL}\right)^{-278} & (\mathrm{r}=0.990) 2.75 \mathrm{~mm}<\mathrm{BL}<10.2 \mathrm{~mm} \\
\mathrm{BD}=4.087 \times 10^{-1} \mathrm{BL}^{0.923} & (\mathrm{r}=0.995) 10.2 \mathrm{~mm}<\mathrm{BL}<28.3 \mathrm{~mm} \\
\mathrm{BD}=4.536 \times 10^{-1} \mathrm{BL}^{0.991} & (\mathrm{r}=0.997) 28.3 \mathrm{~mm}<\mathrm{BL}<124.4 \mathrm{~mm}
\end{array}
$$

$\mathrm{UJL}=4.855 \times 10^{2} \mathrm{BL}^{1.75 \%}(\mathrm{r}=0.974) 2.64 \mathrm{~mm}<\mathrm{BL}<5.14 \mathrm{~mm}$

$\mathrm{UJL}=1.368 \times 10^{-1} \mathrm{BL}^{1.125}(\mathrm{r}=0.967) 5.14 \mathrm{~mm}<\mathrm{BL}<10.3 \mathrm{~mm}$

$\mathrm{UJL}=2.897 \times 10^{\mathrm{B}} \mathrm{BL}^{\mathrm{H} 8103}(\mathrm{r}=0.980) 10.3 \mathrm{~mm}<\mathrm{BL}<33.4 \mathrm{~mm}$

UJL $=2.473 \times 10^{1} \mathrm{BL}^{0.848}(\mathrm{r}=0.991) 33.4 \mathrm{~mm}<\mathrm{BL}<124.4 \mathrm{~mm}$ 


$$
\begin{aligned}
& \mathrm{ED}=8.631 \times 10^{2} \mathrm{BL}^{1.652} \quad(\mathrm{r}=0.984) 1.54 \mathrm{~mm}<\mathrm{BL}<10.1 \mathrm{~mm} \\
& \mathrm{ED}=1.956 \times 10^{-1} \mathrm{BL}^{0.698} \quad(\mathrm{r}=0.935) 10.1 \mathrm{~mm}<\mathrm{BL}<124.4 \mathrm{~mm} \\
& \mathrm{PAL}=6.385 \times 10^{-1} \mathrm{BL}^{0.551} \quad(\mathrm{r}=0.892) 1.54 \mathrm{~mm}<\mathrm{BL}<3.16 \mathrm{~mm} \\
& \mathrm{PAL}=2.917 \times 10^{-1} \mathrm{BL}^{1.230}(\mathrm{r}=0.990) 3.16 \mathrm{~mm}<\mathrm{BL}<4.29 \mathrm{~mm} \\
& \mathrm{PAL}=2.319 \times 10^{-4} \mathrm{BL}^{1.389} \quad(\mathrm{r}=0.990) 4.29 \mathrm{~mm}<\mathrm{BL}<9.44 \mathrm{~mm} \\
& \mathrm{PAL}=4.208 \times 10^{-1} \mathrm{BL}^{1.123}(\mathrm{r}=0.999) 9.44 \mathrm{~mm}<\mathrm{BL}<30.2 \mathrm{~mm} \\
& \mathrm{PAL}=6.326 \times 10^{\prime} \mathrm{BL}^{\mathrm{L} .004}(\mathrm{r}=0.999) 30.2 \mathrm{~mm}<\mathrm{BL}<124.4 \mathrm{~mm} \\
& \text { DVA }=3.636 \times 10^{-2} \mathrm{BL}^{1.774}(\mathrm{r}=0.898) 5.79 \mathrm{~mm}<\mathrm{BL}<10.1 \mathrm{~mm} \\
& \text { DVA }=1.140 \times 10^{-1} \mathrm{BL}^{1.85:}(\mathrm{r}=0.991) 10.1 \mathrm{~mm}<\mathrm{BL}<33.2 \mathrm{~mm} \\
& \mathrm{DVA}=2.551 \times 10 \mathrm{BL}^{1.046}(\mathrm{r}=0.996) 33.2 \mathrm{~mm}<\mathrm{BL}<124.4 \mathrm{~mm} \\
& \mathrm{PDL}=2.821 \times 10^{-1} \mathrm{BL}^{1.096}(\mathrm{r}=0.962) 4.66 \mathrm{~mm}<\mathrm{BL}<10.7 \mathrm{~mm} \\
& \mathrm{PDL}=3.846 \times 10^{-1} \mathrm{BL}^{0.964}(\mathrm{r}=0.987) 10.7 \mathrm{~mm}<\mathrm{BL}<28.1 \mathrm{~mm} \\
& \mathrm{PDL}=4.529 \times 10^{1} \mathrm{BL}^{0.915}(\mathrm{r}=0.994) 28.1 \mathrm{~mm}<\mathrm{BL}<124.4 \mathrm{~mm}
\end{aligned}
$$

As well as in the case of BL-BW relationships, three-grouped marked changes in body proportions corresponding to the morphological transitions indicated above were observed: the changes in the first group were concentrated at $4-5 \mathrm{~mm}$, in the second group at $8-11 \mathrm{~mm}$, and in the third group at $30-35 \mathrm{~mm}$ BL. Relative body proportions exhibited strong positive growth until the larvae attained about 4-5 mm BL where the flexion of notochord took place. After that, the development of the caudal fin followed by the notochord-flexion made the relative values decrease until they reached the juvenile stage. At the juvenile stage, the relative values of TL, BD, and PDL displayed almost constant levels, but the relative values of head organs (HL, ED, UJL) showed negative growth. On the other hand, the relative proportions of PAL and DVA, closely related to the development of digestive organs, exhibited clear positive growth. After these inflexions, the relative growth did not change significantly again until the fish reached $30-35 \mathrm{~mm}$ BL.

\section{Early development of laboratory-reared giant croaker}

To produce fish fry successfully, a basic biological understanding of the early development of the target fish is required. Generally, when marine fishes transform from the larval to juvenile stage, they undergo dramatic changes with morphological and organogenetic changes called "Metamorphosis". Particularly in those marine fishes that produce pelagic eggs, yolk-sac larvae have very poor swimming ability and depend on the yolk for nourishment. After the yolk is absorbed, they start to develop transient larval characters such as pigment pattern, underdeveloped fins and digestive system (Tanaka, 1969a, b; Kendall et al., 1984; Fukuhara, 1992). During the long larval period, the characteristics of the adult gradually develop. At the end of the larval stage, they go through an abrupt or a prolonged transformation period to juvenile stage. During this transitional period, externally all fin-rays are formed and initial scales appear (Kendall et al., 1984; Fukuhara, 1992; Yoshimatsu, 1996), and internally the rudimentary pyloric caeca appear in the digestive system (Tanaka, 1971). These morphological changes are 
also synchronized by a change from pelagic to demersal habits. Moreover, during the transformation from the juvenile to young stage, fin-segmentation, fin-branching and squamation are completed, and the skeleton system is also completely ossified (Matsuoka, 1985), the larval pigment pattern is overgrown or lost and replaced by dermal pigment similar to that of the adults, and the body shape approximates that of the adults as well (Kendall et al., 1984). Their digestive system closes to that of the adults as well (Fukusho,1972; Yoshimatsu et al., 1993). These changes were also observed in laboratory-reared giant croaker in the present study. It also should be emphasized practically that during these periods, fish with weak physiological condition must be dealt with carefully. (Fukuhara, 1976).

Fukuhara (1992) demonstrated that the change of life mode (habitation, feeding, and behavior) was linked closely with the morphological and ontogenetic development of teleost fishes. Changes in body proportion, i.e. growth inflexions usually concentrate at the transformation periods from larval to juvenile stages and from juvenile to the following stage (Kitajima, 1988, 1991; Yoshimatsu et al., 1992, 1993). As shown in Fig. 10, the result of the present study on relative growth shows that major changes in morphometrical characteristics took place concurrently with the organogenesis and behavioral changes in the early life stage of giant croaker. Consequently, the changes that

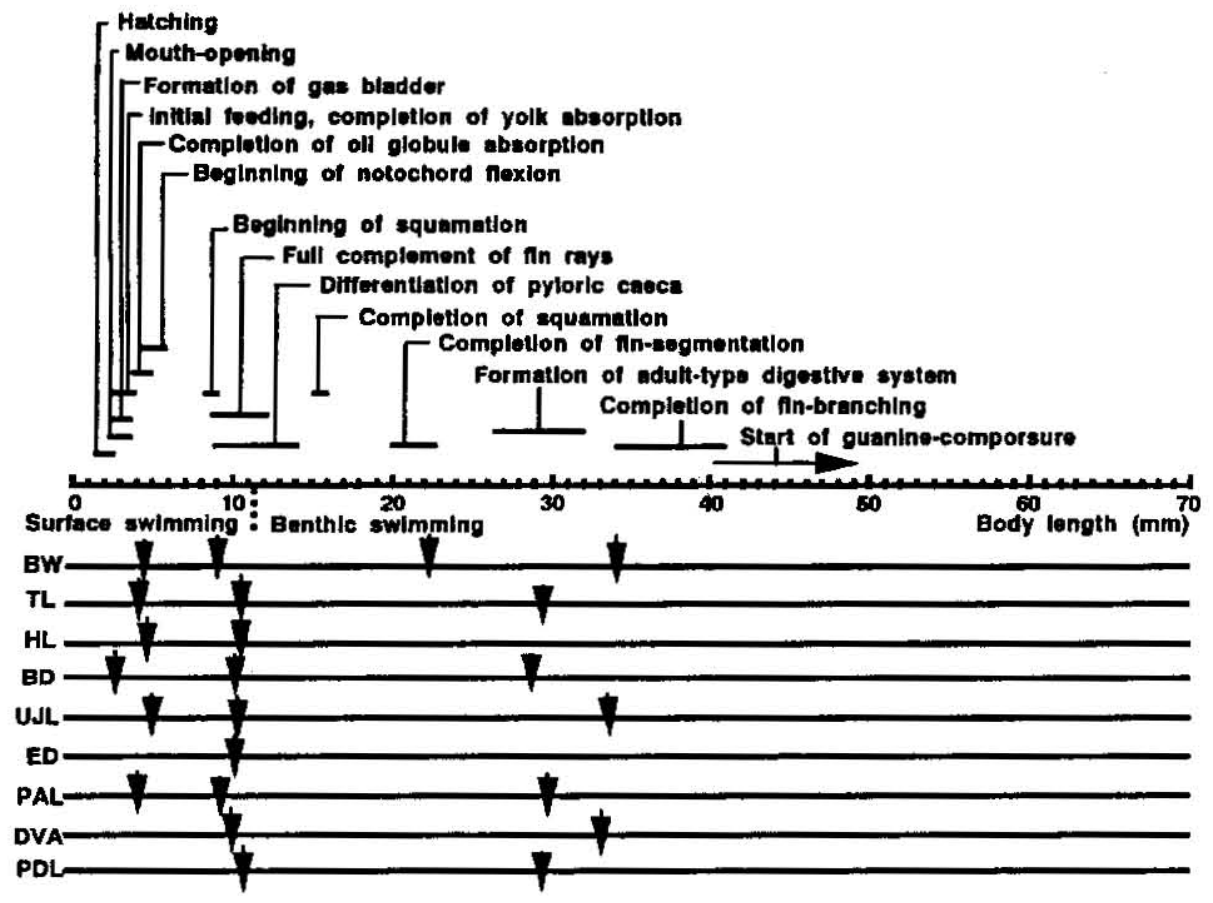

Fig. 10. Sequence of early development of reared Nibea japonica. Refer to Figs. 8 and 9 for BW, TL, HL, BD, UJL, ED, PAL, DVA. and PDL. Arrows show growth inflexions. 
were observed at $8-14 \mathrm{~mm}$ and $30-35 \mathrm{~mm}$ BL are regarded as corresponding to two important morphological transitions, namely the beginning and the end of the juvenile stage.

It was reported previously that melanophores on the body surface of sciaenid fish disappear clearly at the transformation period from the juvenile to young stages (Takita, 1974; Taniguchi, 1979, 1982). Present results agreed well with those observations. This change in pigment pattern could be used as one of the external criteria to distinguish juvenile from young sciaenid fish. From the viewpoint of ontogenesis, young with nearly completed adult-like body systems should be able to tolerate rough-handling and starving, and the more tolerate of various environmental changes than those in earlier stages. Therefore the giant croaker fry with silvery body surface should be ready for restocking or moving to the successive intermediate rearing process in their culture.

Understanding morphological and behavioral changes during the early life history of target species is important in choosing suitable rearing conditions, and feeding schedules for successful seedling fry production. Nevertheless we still have very limited knowledge on the early life history of sciaenid fishes. So further investigations about them would be necessary for establishing fry production technology for these species.

\section{ACKNOWLEDGMENTS}

The authors are indebted to the staff of the Miyazaki Prefectural Fish-Farming Association for their cooperation in supplying the experimental material. We also thank Dr. Chikara Kitajima, the former Professor of Kyushu University, for drawing our attention to this research and for his indispensable guidance. Thanks also are extended to the staff of the Fishery Research Laboratory of Kyushu University for their help in the experiment.

\section{REFERENCES}

El-7ibdeh, M., Ide, K., Yoshimatsı, T., Matsui, S., and Furuichi, M., 1995a Requirement of yellow croaker Nibea albiflora for dietary phosphorus. I. Far. Agr., Kyushu Lniw, 40: 147-155

El-Zibdeh, M., Ide, K., Yoshimatsis, T., Matsui, S., and Furuichi, M., 1995b Efferts of the deletion of (.a or Irace elemerts from semi-purified dict on growth and feed nilization of yellow croaker, Nibea albiflora. J. Fac, Agr., Kyushu Uniw, 40: 157-166

El-Zibdeh, M., Ide, K., and Furuichi, M., 1995c Elfects of the deletion of Mg or Fe from semi purificd dict on growth and feed ulilization of yellow croaker Nibea albiflora. J. Fac. Agr., Kyushu Univ., 40: $391-397$

Fukuhara, O., 1992 Sludy on the development of functional morphology and bchavior of the larvac of eight commercially valuable teleost fishes. Cont. Fish. Res. in the Japan Sea IJlock, 25: 1-112

Fukusho, K., 1972 Organogenesis of digest.jve system in the mullet, Liza harmatocheila, with special reference to gizzard. Japan J. Ichthyol., 19: 28:3-294

Han, K. -N., Yoshimatsu, T., Matsui, S., Furuichi, M., and Kitajima, C., 1994 Effect of dietary protein level on growth and body composition of eroaker, Nibea albiflora. Suisanzoshoku, 42: 427-4,31

Kendall, A. W, Ahlstron, E. H., and Moser, H. (i., 1984 Larly life history stages of fishes and their characters. In "Ontogeny and Systematies of fishes", ed. by Moser, H. G. et al., Am. Soc. Ichthyol. Herpetol., Spec. Publ. No. I, Allen Press, Lawrence, KS, pp. 11-22

Kitajima, C., Hayashida, G., and Yasumoto, S., 1988 Early development of the laboratory-reared flouriter, Pleuronighthys cornutus. Japan. J. Ichthyol, 35: 69-77

Kitajima, C., Takaya, M., Tsukashima, Y., and Arakawa, T., 1991 Development of eggs, larvae and 
juveniles of the grouper, Epinephelus septemfasciatus, reared in the laboratory. Japan. J. Ichthyol, 38: 47-55

Masuda, H., Amaoka, K., Araga, C., Ueno, T., Yoshino, T., 1984 The Fishes of the Japanese Archipelago. Tokai University Press, Tokyo

Matsuoka. M., 1985 Osteological developmental in the red sea bream, Pagras riajor. Japan J. Ichthyol. 32: $35-51$

Ochiai, A. and Tanaka, M., 1986 Ichthyology, Vol. II. Kouseisha-Kouseikaku, Tokyo, pp.704-723

Tabaru, T, Nasu, T., and Ishibash, O., 1988 Studies on the seedling production of Japanese croaker Nibea juponica-1. Brecding of spawner and egg collection. Suisanzoshoku, 35: 265-270

Takeda, H., Kesamaru, K., Kuroki, A., Yuda, H., and Yamada, T., 1994 Seasonal variations in nutritive components in muscle of cultured Japanese croaker, Nibea japonica. Suisanzoshoku, 42:179-183

Takita. T., 1974 Studies on the early life history of Nibea albiflora (Richardson) in Ariake Sound. Bull. Fac: Fish., Nagasaki Univ., 38:1-55

Tanaka, M., $1969 \mathrm{a}$ Studies on the structure and function of the digestive system in teleost larvae-J. Development of the digestive system during prelarval stage. :Japan J. Ichthyol., 16: 1-9

Tanaka, M., 1969b Studies on the structure and function of the digestive system in teleost larvae-It. Characteristics of the digestive system in larvae at the stage of first feeding. Japan J. Ichtryol., 16: 41-49

Tanaka, M., 1971 Studies on the structure and function of the digestive system in teleost larvae-III. Development of the digestive system during postlarval stage. Jupan J. Ichthyol., 18: 164-174

Taniguchi, N., Kuga, T., Okada, Y., and Umeda, S., 197!) Studics on the rearing of artificially-fertilized larvae and the early developmental stage of the nibc-croaker, Nibea mitsukurii. Rept. Usa Mar. Biol.Inst., 1: $51-58$

Taniguchi, N., 1982 Biology of sciatenid fishes-V. Early developmental stages. Aquabiology, 20: $210-215$

Tsukashima, Y. and Kitajima, C., 1982 Rearing and development of larval and juvenile silver bream, Sparus sarba. Bull. Nagasaki Pref. Inst. Fish., 8: $129-136$

Yoshimatsu, T., Matsui, S., and Kitajima, C., 1992 Early development of laboratory-reared redlip mullet, Liza haematocheila. Aquaculture, 105: 379-390

Yoshimatsu, T., Matsui, S., and Kitajirna, C., 1993 Early development of laboratory-reared keelback mullet. Nippon Suisan Gakkaishi, 59: 765-776

Yoshimatsu, T., 1996 Early fin-development and squarnation of laboratory-reared redlip mullet, Liza haematocheila. Sci. Bull. Fac. Agr, Kyushu Univ., 50: 16:3-171 